[Das, D. (2008). A Case for Place-based Education: Learning to Make a Difference in the Raumati Wetlands. New Zealand Annual Review of Education, 17, 125-143]

\section{A Case for Place-based Education: Learning to Make a Difference in the Raumati Wetlands}

\section{DAS}

\section{Abstract:}

Alongside the UNESCODecade of Education for Sustainable Development, the New Zealand Curriculum endorses environmental education and agrees that learners need to be educated for a future in which they can safeguard the environment alongside their place in it. However, in practice, environmental education is often seen as a non-mandatory add-on which robs schools of precious time reserved for core subjects. This article builds on previous comment and shows how schools can use place-based education to effect meaningful change in their local environment, whilst effectively covering most aspects of the school curriculum. By becoming involved in local issues, students can develop understandings of the democratic process, business development, conservation and regeneration of species through the relationships between these often conflicting factors. A combination of research discussion and local media releases on current environmental debate provides a platform for meaningful contribution via the New Zealand Curriculum.

$\mathrm{F}$ or most of my life I have been interested in matters to do with the environment - my environment. I grew up in Raumati South from the age of five to eighteen, and returned in my thirties to raise my family here, settling across the road from the northern end of Queen Elizabeth Park. This area houses a small wetland, and twenty years ago the evening air was abuzz with croaking frogs - today it is silent. At certain times of the year in wet weather the frogs would migrate across the road, making a hazardous journey against the traffic, and we would often startle a transient frog in our garden. I have not seen this phenomenon for years.
The road edge of the Poplar Avenue wetland was previously protected by a stand of willows, but in 1999 these were removed and a portion of the swamp filled with sand to support a new dwelling. This left an unsightly area of bare land where I initiated a community planting of native trees, kanuka and flaxes to restore the wetland environment and beautify the entrance to our district. The Raumati South Residents' Group (RSRG) has since conducted other plantings, and a local young offender served his community work in the garden, but I remain concerned about the state of the animal life in the swamp and its future as a viable ecosystem. Frogs are biomonitors for the general health of the planet, and are the most likely indicator of the ecological viability of the Raumati South wetlands. When we look intently at the landscapes we inhabit and treasure, we witness their own systems of wisdom and warning. Chemical changes in ecosystems resulting from farming and technology are affecting the health of people, as well as of flora and fauna. This is political ecology and deserves a place in mainstream education (Bowers, 2000; Park, 1996; Price, 2007; "Starting a community project", 1999).

Further east is another impressive stand of kanuka that rests in the path of the proposed Western Link Road. ${ }^{1}$ There is local debate over whether the entry should rather be off the main road instead, but protests from state highway residents are more in the $\mathrm{NIMBY}^{2}$ category, whereas Raumati South protests revolve around protecting the fragile environment. Similar concerns are expressed at the northern end of the original Wharemauku swamplands. Friends of Te Hapua Dunes and Wetlands group oppose development of largely untouched coastal land designated as a heritage site in the district plan. They say it is also one of the last remaining wetlands of its kind in the area and its protection is crucial. The health and future of these signature areas of dwindling wetlands provide a timely and appropriate context for place-based education that could make a significant difference to this community. There are four primary schools nearby, and two colleges not far away, whose students could contribute to their environment, whilst at the same time fulfilling their own educational development. Indeed Te Ra Waldorf Steiner School sits adjacent to the kanuka wetland and is already involved in sustainability issues, with a reputation as an environmentally friendly school. Meanwhile other schoolchildren in the district are involved in sustaining the beach and dune environments, saying they feel they are doing something worthwhile and enjoy 
"helping out nature" (Askew, 2007; Blundell, 2007; Gurunathan, 2007; Haxton, 2007).

The combined energy of people makes communities vibrant.

(Raumati South Residents' Group, 2007)

\section{Status of Environmental Education in New Zealand}

The overall purpose of education is to prepare, equip and empower the next generation for the future, whether that learning be at home, at school or in the community, and this means so much more if they are actively participating in that future right now. Children are constantly asked by adults "what do you want to be when you grow up?" which diminishes who and what they already are as people contributing to society. Anne Sturgess (2007) argues that children, rather than identifying sports people as heroes, need to be given the chance to find the hero within themselves and their immediate environment, family, community and culture. Unfortunately the current educative response to future needs appears solely focused on perceived technological, digital and occupational needs, instead of also preparing future generations for new realities of the environmental and social issues they are sure to encounter. It is hard to understand why concern for ecosystems is not seen as an essential part of education policy for social justice, considering how adverse findings on toxic by-products along with their effects on the environment are so well-reported. An eco-justice based approach would take into account our extreme weather patterns, global warming, economic systems, fossil fuel and synthetic chemical usage, effects on human life, extinction of species and the practice of poorer countries being paid to accept toxic waste at the expense of their own people (Bowers, 2001; Hutchinson, 2004).

The Ministry of Education has reported the need for the New Zealand Curriculum to emphasize the importance of Education for Sustainability and recognises that education must prepare learners for a future in which they can safeguard and enhance the environment along with their place in it. It says "effective environmental education will occur when students' learning needs are considered and when the issues chosen are meaningful and relevant to them" (Ministry of Education, 1999, p. 1).

However, Environmental Education (EE) is not subject to the same funding, professional development, assessment, and reporting requirements as core subjects are, although in the last few years central and local government have provided funding and support for schools and teachers to develop their own EE programmes. The employment of regional EE coordinators and pilot funding of some schools suggests a legitimate place for EE in New Zealand schools, but it is still dependent on the commitment of the school community, and some schools are showing the way by formalising their commitment via policy and planning documents (Bolstad, 2005).

\section{Status of Place-based Education in Schools}

The concepts of place-based education, environmental education and education for sustainability are not so easily implemented in practice, and, when offered, have focused on education "in" and "about" the environment rather than "for" the environment. Place-based education provides children with the knowledge and experiences necessary to participate in the democratic process, and recent topical issues in the Kapiti district provide a perfect context for this learning to thrive. They reveal conflicts of interest between property development groups and residents over roading, as well as hospital, airport and Landcorp lands, resulting in proactive bodies being set up to counteract short-sighted profit-driven policies supported by the local Council. "Kaitiaki of Whareroa" opposed the quick-fire sale of the government farm and retained a portion in public ownership with the support of the late Rod Donald, ${ }^{3}$ and conservation groups are now organizing schoolchildren and residents to replant the area with native trees. Funding from the Ministry of the Environment in 2006 and 2008 is enabling the Whareroa Guardians Trust to plant over 10,000 trees to extend the corridor of native bush from Kapiti Island to the Tararua Ranges. By being involved in this kind of activity, students can start to understand how the educational, economic, and ecological branches of the community are related to one another, rather than simply view them as stand-alone entities (Fox, 2008; Gurunathan, 2007; Sobel, 2004; Woodhouse, 2000).

If schools were to adopt PBE [place-based education] as a central concept environmental education would emerge as an obvious context for students to practice being "place-conscious" and "place-makers" in their own school and communities. (Bolstad, 2005, p. 230).

Woodhouse (2000) sees education for sustainable development (ESD) as a combination of environmental education, outdoor education (OE) and place-based education. OE provides meaningful outdoor experiences; 
EE develops citizens committed to living without damaging the local environment and PBE is community-oriented ecological education. Initiatives supported by Maori over time, like Kura Kaupapa Maori, have an affinity to PBE yet are beneficial to all students, educationally and culturally. A Maori world-view includes the integrated whole of universe, matter and spirit as a holistic approach to people and their environment. While lifelong learning searches for answers to the ultimate "why?", modern science searches more for the short-term immediate "why?", with a disjunction between material and spiritual values. Instead, knowledge of cultural groups and inter-generational experience of place is undermined and ignored by modernism and media, so it is hard to build recognition of place-based education in this climate (Bolstad, 2005; Bowers, 2001; Marsden, 2003). The new New Zealand Curriculum (2007) opens by addressing these attitudes with a vision of young people as lifelong learners with a sustainable social, cultural, economic and environmental future in New Zealand.

Bolstad suggests the transformative nature of $\mathrm{EE}$ is in conflict with the views of conventional schooling, which actually reproduces current societal norms that in turn result in environmental and social injustices. She claims environmental education is seen as "transgressing what is viewed as normal or acceptable for students to be doing at school" (p. 223). Her research showed that there was high enthusiasm for EE within funded pilot schools, but in reality it had a lesser status in the curriculum and in many cases was taught on an ad hoc basis as an add-on by only a few enthusiastic teachers. There was sometimes a lack of support from colleagues, no leadership or sustainability, and a strong dependence on key people for energy and expertise. For example, at Christchurch Girls' High School, students reported that other teachers made negative comments about the Sustainable Futures course, and peers did not view it as a serious subject (Bolstad, 2005, p. 228). Constrained by structured timetables, assessment demands, lack of integration across the school curriculum, and the task of getting Boards of Trustees and staff "onside", it is not difficult to see how EE and ESD could be too hard to contemplate or sustain. Schools are restrained by the structural characteristics of society, and dreamers of change are often seen as disruptive to the structures already in place. But I would argue we still need to transform and reform both educational and ecological practice (Bowers, 2001; Brown \& Dannenmann, 2002).

No matter how effective the teachers and no matter how empowering the curriculum, the educational process lacked the political means necessary to transform the controlling political and economic interests. (Bowers, 2001, p. 1)

At a school organizational level, practical changes need to be made to make place-based, environmental and sustainable education happen. A further challenge presented by the new national curriculum to school and classroom curricula is that they need to be aligned to the document and be future-focussed, because these issues present a rich source of learningopportunity. Sustainability issues explore "the longterm impact of social, cultural, scientific, technological, economic or political practices on society and the environment' (Ministry of Education, 2007, p. 39). Schools need to examine their hidden curriculum to determine how much they support the status quo and how much they consider their physical, social and cultural environments, much as other models such as peace education and Te Kura Kaupapa Maori do. Bolstad (2005, p. 30) identifies three levels of change:

1. Pedagogical level - schools create stimulating and meaningful learning experiences, involving pupils in eco-ways of thinking, acting and feeling in school, family and community (responsibility and integrity).

2. Social/organisational level - schools build and cultivate a culture of communication, respect and shared decision-making (ownership and empowerment).

3. Technical/economic level - schools become ecologically sound themselves, with economic and sustainable use of resources.

\section{Authentic Contexts Where the Urgency is Now}

When we assess where we are at ecologically, there is a sense of urgency and an awareness of the importance of our time. While it is not children's responsibility to heal the world they have inherited, schools can focus and create a sphere in which students can problem-solve and act now to influence their communities. The new New Zealand Curriculum (2007) includes requirements and guidelines which offer more support for place-based education. Even at Level One it involves taking individual and collective action "to contribute to environments that can be enjoyed by all." Children are encouraged to identify, promote, plan and implement programmes to benefit their local environments. For students to participate in place-making, their school learning needs to have visible and meaningful connections to local, national and international contexts for knowledge and resources 
(Bolstad, 2005; Brown \& Dannenmann, 2002; Ministry of Education, 2007). The national curriculum also recommends that students use their increasing science knowledge to consider issues of concern by exploring a wide range of aspects, and making decisions for action. They are advised to investigate media reports and influences that relate to community resources and affect well-being, while also asking questions and finding evidence to support their ideas.

When we witness local and global indications like diminishing butterfly populations and the disappearance of frogs, this tells us the time to act is now. In many regions of New Zealand people are breeding and tagging monarch butterflies to release into the wild. Place-based education in school science studies could become part of this nationwide study of monarchs, which is then aligned to similar research in the United States. Children can learn the interconnection between insects and plants; butterflies and pollination, as well as the impact of insecticides and herbicides on declining species of flora and fauna. Instead of a passing curiosity with one spindly swan plant and a few eggs in the classroom, students could contribute meaningfully to the numerous initiatives set up under <www.monarch.org.nz $>$ by breeding plants and butterflies for monitoring and release (" 'Common' butterflies fighting for survival", 2007; Irvine, 2007; Light, 2007; Ministry of Education, 2007).

We are living in a watershed period comparable to the major shift that took place from the medieval to the modern world. (O'Sullivan, 1999, p. 2)

A similar venture could be undertaken for breeding and releasing frogs to impact the eco-system of the Raumati wetlands. Gone are the days when we dissected frogs in biology classes. Thankfully now this basic anatomy can be taught via <www.frogguts.com $>$ virtual dissection software. Dr Phil Bishop of Otago University is asking people to send him information about frog populations for his New Zealand frog survey on both indigenous and introduced species, so students could contribute to this national research while contributing to their local wetlands. Field trips and school camps could involve visiting thriving wetland communities to witness how their local equivalent could eventuate. The Otago University website states:

One of the keys to balanced land management is an understanding of the ecological processes responsible for the support of diverse forms of life, irrespective of their commercial value. (Price, 2007)
There are numerous alarm bells in the natural environment that can trigger action in individuals, groups and whole communities. For teaching and learning to be truly student-centred and self-directed, students can consult and interact in their communities to identify their own areas of concern. That is not to say that participation in other communities is not worthwhile; these can provide experience and skills which can be transferred to newly identified activities and areas of study. At Level Six in the Health and Physical Education Curriculum, students investigate the roles and effectiveness of local, national and international organisations that promote well-being and environmental care, evaluating their own values and practices as they do so (Ministry of Education, 2007).

To illustrate: Whilst swamp birds like the pukeko are prolific nationally, the few breeding pairs that grazed along the edge of the Raumati wetlands have all succumbed to road kill. They added character to the area and are now gone. Relocating more, with pukeko warning signs along the avenue, could be a "cool" project for local schoolchildren to undertake while communicating an environmental message to the community. If this sort of activity is chosen, by younger students for example, it can empower them to do something before a species becomes endangered. A small experience at local level can provide the model for larger ventures later in life. This district is enjoying the resurgence of the tui in my lifetime, but there is still much planting to be done to create a corridor for native species to travel from north to south, east to west, unimpeded. It is no longer sufficient to have thriving bird populations on a handful of offshore islands only.

Other birds have disappeared from the Queen Elisabeth Park area and efforts are being made to conserve and revive their numbers nationally. For example, not many people know that although the karewarewa (New Zealand native falcon) graces our \$20 note, it is more endangered than the kiwi, creating a fascinating study of its own. It used to be resident in the park. By raising local awareness with accurate information and strategies for action, ordinary citizens who are not ornithologists can make a real difference for our endangered species. Vintners in the South Island are erecting breeding boxes for falcons, which in turn keep down populations of vermin and sparrows from the crops. On the East Coast, following education from DOC and the timber company, loggers halted work in an area where falcons were nesting until the chicks had fledged and flown the nest (Fox \& Wynn, 2007; Jones, 2008). 
Examples such as these can be useful as working models of what is being attempted locally and nationally, but student-directed studies encourage real participation in environmental sustainability and citizenship. A key competency for young people, as identified in the curriculum, is being able to relate to others as contributing members of the community. Another is in the thinking process involved in being creative and critical to make sense of experiences and ideas.

These processes can be applied to purposes such as developing understanding, making decisions, shaping actions or constructing knowledge. Intellectual curiosity is at the heart of this competency.

(Ministry of Education, 2007, p. 12)

\section{Using History as Our Guide}

Park (1996) tells of how schoolchildren revegetated Te Mome stream in Lower Hutt following a botulism outbreak that decimated the local bird population. They found out that they could create shelter to reduce the risk of botulism, learned how the riverbank had been six generations ago, and imagined what it could be like six generations on from 1990. They linked the history of their area to the present and to the future.

Go into a lowland kahikatea forest in autumn when its koroi are ripening, lie under the towering trees listening to the cacophony of birds and the constant patter of inedible bits hitting the leaves around you, and you'll know what "groves of life" mean. These are ecosystems that are now, like huia and kakapo, vanished or down to few. (Park, 1996, p. 15)

Huia were once endemic on the Raumati coast, but kahikatea swamps, which lined the tract between sandhills and escarpment, are now gone. Only their stumps remain, following years of felling, peat fires and drainage into farmland. But they can remind young people of what has been lost and guide them to protect what is left. Macmorran (1977) tells how the settlers of 165 years ago failed to visualize future erosion and death of birds, so cut the forests so that only small pockets remain. She also describes how the extensive swamp area originally extended from Paekakariki northwards to Waikanae, between the dunes and the Tararua foothills, and was used as canoe passage by Maori (pp. 55, 105). We cannot expect to restore all of this to how it once was, but schoolchildren can be encouraged to envisage a "high forest to within a mile and a half of the beach, with swamps full of flax and a belt of sand hummocks.... It is hard to imagine a forest that has gone without a trace" (Park, 1996, p. 112).
Rangitane o Wairarapa (2005) also record that wai tapu swamps were part of crucial inland waterways, and that wetlands are excellent filters of dirt coming from the land. They were used for hiding and preserving taonga, and formed part of the lifeblood of Papatuanuku. Unfortunately "progress" has viewed wetlands as wastelands to be drained and transformed into "productive" land. Kapiti Coast District Council (KCDC) still displays posters in its Resource Consent office urging us to preserve our wetlands, yet it authorizes the ongoing destruction of this precious eco-system. This is only paying lip-service, and despite good intentions there is a reluctance to question prevailing assumptions and attitudes. This in turn reinforces the thinking that perpetuates the problem, while others trivialize the history of colonial beginnings and see no relevance to contemporary New Zealand life. Progress-versus-preservation arguments divide the community on issues such as a rare orchid on airport land, pine forests taking over the eastern skyline and continued destruction of wetlands (Gurunathan, 2007; Park, 1996)

If community concerns were more clearly heard, and if active participation in local environmental issues was promoted as exemplary rather then deviant behaviour, ordinary people could have more impact on local outcomes. Often development decisions are made behind closed doors, and local government usually has access to superior legal representation outside the reach of ordinary citizens. Environmental and place-based education have a role here in fostering a connection to land and environment and creating young citizens confident and positive in their own identity. In doing so, it could discourage the complacency and apathy so often displayed in the face of overwhelming developmental and commercial drive. The Healthy Communities and Environments curriculum requires students at Level Seven to evaluate laws and analyse how the environment and well-being of the community is affected by population pressure and technological processes (Ministry of Education, 2007). To cite Bowers again, "The more that needs are met through the self-reliant capacities of individuals, families and communities, the fewer the adverse impacts on the environment" (2001, p. 9).

\section{School Curriculum for Place-based Environmental Education}

The historical, current and future viability of the remainder of the Wharemauku swamp provides an ideal setting for place-based education for schools and community at large in Raumati South and 
beyond. It gives a centre and purpose for students to identify and collaborate around, and there is a wealth of knowledge and experience, plus commitment and expertise to call on, within the local community.

Bolstad (2005) cites Penetito's three basics of PBE as "Who am I? Where am I? What is this place and how do we fit into it?" Schools could use these to focus curriculum and instruction on helping students understand and appreciate their immediate surroundings, and so develop it through an ecological lens. Environmental education can occur both inside and outside the classroom, but place-based education takes children out into their local environment and community to achieve ecological and cultural sustainability. It uses the local environment to teach concepts in language, mathematics, social studies, arts - indeed across the whole curriculum. The use of local stories about the wetlands, flora and fauna can be a catalyst for young students reluctant to engage with science. Science thinking is cognitively challenging because it is abstract, and needs to be translated into everyday experience and tangible concerns. A school curriculum based around the revival and preservation of the wetlands could facilitate this, while at the same time establishing and fostering an ecological identity in children (Bowers, 2001; Gilbert, 2005; Sobel, 2004; Woodhouse, 2000).

One of the barriers to schools and teachers committing to place-based education is the perceived time necessary to create new opportunities and resources on topics which may require extensive new reading and supporting research. Organisations like the Karori Wildlife Sanctuary have produced free science and social studies resource packs for teachers on topics such as Restoration - A 500 Year Vision. This programme shows how survival of plants and animals depends on successful competition for resources, and the importance of habitat protection which often competes with property development, transport requirement and business needs. At Level Eight of the new curriculum, students critically analyse inter-relationships between people, industry, technology and legislation on aspects of environmental health (Ministry of Education, 2007). Another resource pertinent to the Raumati Wetlands curriculum is Te Kete Ipurangi's (TKI's) Biodiversity in New Zealand Wildlife which shows how people's activities influence places and how ideas and actions of people change the lives of others. Classes can visit the Karori Sanctuary and staff will visit the classroom to provide integrated learning experiences which correlate with achievement objectives in National Curriculum documents. Other resources are virtual tours and fieldtrips organised for both primary and secondary school levels by LEARNZ, ${ }^{4}$ an on-line education programme for students in New Zealand state, integrated, and private schools Students stay at school but visit places they would never otherwise go to and interact with people they would never otherwise meet. Topics include Making Sense of the Living World and Place and Environment, covering science, social studies, physics, geography, agriculture, technology and the arts. Teachers can book their classes in for study topics under the themes such as People and the Environment, Environmental Education, Environmental Impact and Environmental Issues. (Karori Wildlife Sanctuary, 2008; LEARNZ, 2008)

\begin{tabular}{|c|c|c|c|}
\hline \multicolumn{4}{|c|}{ Curriculum Outline for Environmental Sustainability \& Place Based Education } \\
\hline Curriculum Area & Learning Outcomes & Activities & Resources \\
\hline $\begin{array}{l}\text { Social Sciences/ } \\
\text { History: } \\
\text { Wetlands study } \\
\text { and plan for future }\end{array}$ & $\begin{array}{l}\text { Students will show } \\
\text { understanding of } \\
\text { the history of } \\
\text { settlement of their } \\
\text { local area by: }\end{array}$ & $\begin{array}{l}\text { Gathering histories of area } \\
\text { including Ngati Maru, } \\
\text { land use: holiday homes, } \\
\text { dormitory town, } \\
\text { agriculture, commercial; } \\
\text { investigate environmental } \\
\text { impact of each. Current } \\
\text { events }\end{array}$ & $\begin{array}{l}\text { Te Ati Awa, Raukawa and Ngati } \\
\text { Toa Iwi, residents, historians, } \\
\text { library, internet, teachers, } \\
\text { Raumati South Residents' Group } \\
\text { (RSRG), KCDC, local books: } \\
\text { Carkeek (1967), Macmorran } \\
\text { (1977), History Classroom } \\
\text { <www.nzhistory.net.nz> }\end{array}$ \\
\hline $\begin{array}{l}\text { Social Sciences/ } \\
\text { Geography: } \\
\text { Wetlands study } \\
\text { and plan for future }\end{array}$ & $\begin{array}{l}\text { Students will } \\
\text { demonstrate } \\
\text { familiarity with their } \\
\text { location by: }\end{array}$ & $\begin{array}{l}\text { Mapping their local } \\
\text { district: wetlands, sand } \\
\text { dunes, grasslands, trees, } \\
\text { hills, beach, roads, } \\
\text { residential. } \\
\text { Relief drawings, weather } \\
\text { patterns, erosion, soil types }\end{array}$ & $\begin{array}{l}\text { KCDC records, local surveyors, } \\
\text { Greater Wgtn Regional Council } \\
\text { (GWRC), DOC, teachers, airport } \\
\text { MET office, local environmental } \\
\text { groups, Kiwi Conservation Club, } \\
\text { virtual fieldtrips } \\
<\text { <ww.learnz.org.nz }>\end{array}$ \\
\hline \begin{tabular}{|l} 
Science/ \\
Biology: \\
Wetlands study \\
and plan for future
\end{tabular} & $\begin{array}{l}\text { Students will gain } \\
\text { knowledge of local } \\
\text { living organisms } \\
\text { and the } \\
\text { interconnection } \\
\text { between insects and } \\
\text { plants by: }\end{array}$ & $\begin{array}{l}\text { Tracking \& recording local } \\
\text { frog populations by } \\
\text { sightings \& listening; } \\
\text { breeding frogs for release } \\
\text { locally; breed monarch } \\
\text { butterflies and grow swan } \\
\text { plants; record bird } \\
\text { populations }\end{array}$ & $\begin{array}{l}\text { Residents, DOC, GWRC, } \\
\text { scientists and researchers at } \\
\text { Canterbury University, Forest \& } \\
\text { Bird Society, Otago University } \\
\text { Frog Survey, Kiwi Conservation } \\
\text { Club < www.frogguts.com > } \\
\text { < www.monarch.org.nz.> }\end{array}$ \\
\hline $\begin{array}{l}\text { Science/ } \\
\text { Chemistry: } \\
\text { Wetlands study } \\
\text { and plan for future }\end{array}$ & $\begin{array}{l}\text { Students will gain } \\
\text { understanding of } \\
\text { their physical } \\
\text { environment by: }\end{array}$ & $\begin{array}{l}\text { Testing water quality in } \\
\text { wetlands, research ways of } \\
\text { improving water quality to } \\
\text { sustain wildlife organisms } \\
\text { in wetlands and ponds }\end{array}$ & $\begin{array}{l}\text { KCDC Water Treatment staff, } \\
\text { Ministry for Environment, } \\
\text { Chemistry Departments of local } \\
\text { colleges, older students, Karori } \\
\text { Sanctuary resources } \\
<\text { www.sanctuary.org.nz> }\end{array}$ \\
\hline $\begin{array}{l}\text { English Language } \\
\text { \& Media Studies }\end{array}$ & \begin{tabular}{|l} 
Students will \\
develop oral and \\
written language \\
skills
\end{tabular} & $\begin{array}{l}\text { Interviewing; letter } \\
\text { writing; telephone skills; } \\
\text { gaining permission; } \\
\text { reporting for paper }\end{array}$ & $\begin{array}{l}\text { Residents, teachers, KCDC, } \\
\text { media, GWRC, teachers } \\
<\text { www.infoxchange.net.au> }\end{array}$ \\
\hline
\end{tabular}




\begin{tabular}{|c|c|c|c|}
\hline $\begin{array}{l}\text { Horticulture } \\
\text { Wetlands study } \\
\text { and plan for future }\end{array}$ & $\begin{array}{l}\text { Students will gain } \\
\text { knowledge of } \\
\text { endemic and native } \\
\text { flora by: }\end{array}$ & $\begin{array}{l}\text { Recording \& researching } \\
\text { endemic species; growing } \\
\text { seedlings, propagation for } \\
\text { local planting to filter } \\
\text { swamp }\end{array}$ & $\begin{array}{l}\text { KCDC planting guide, GWRC } \\
\text { planting guide, books, internet, } \\
\text { local nurseries, residents, RSRG, } \\
\text { Whareroa Guardians Trust }\end{array}$ \\
\hline $\begin{array}{l}\text { Mathematics: } \\
\text { Wetlands study } \\
\text { and plan for future }\end{array}$ & $\begin{array}{l}\text { Students will } \\
\text { develop mathe- } \\
\text { matical skills by: }\end{array}$ & $\begin{array}{l}\text { Using statistics, graphs, } \\
\text { charts, probability, } \\
\text { population predictions, } \\
\text { measurement to assist } \\
\text { study }\end{array}$ & $\begin{array}{l}\text { Teachers, books, DOC, older } \\
\text { students, Otago University Frog } \\
\text { Survey, Forest and Bird Society } \\
\text { records }\end{array}$ \\
\hline Reading & $\begin{array}{l}\text { Students will } \\
\text { develop reading and } \\
\text { research skills by: }\end{array}$ & $\begin{array}{l}\text { Reading local newspapers, } \\
\text { researching histories, } \\
\text { plans, books, internet }\end{array}$ & $\begin{array}{l}\text { Newspapers, plant guides, } \\
\text { books, environmental } \\
\text { publications, historical records, } \\
\text { environmental websites }\end{array}$ \\
\hline Te Reo Maori & $\begin{array}{l}\text { Students will } \\
\text { increase their } \\
\text { knowledge of Te } \\
\text { Reo Maori by: }\end{array}$ & $\begin{array}{l}\text { Learning Maori names for } \\
\text { district; learn correct } \\
\text { pronunciation of local } \\
\text { tribal and place names; } \\
\text { significance of tikanga and } \\
\text { kaitiakitanga }\end{array}$ & $\begin{array}{l}\text { Residents, Ati Awa, Ngati Toa, } \\
\text { videos, tapes, books, teachers, Te } \\
\text { Wananga O Raukawa }\end{array}$ \\
\hline Art & $\begin{array}{l}\text { Students will } \\
\text { develop artistically } \\
\text { by: }\end{array}$ & $\begin{array}{l}\text { Observing, drawing \& } \\
\text { photographing flora and } \\
\text { fauna; creating publicity } \\
\text { resources }\end{array}$ & $\begin{array}{l}\text { Art supplies, cameras, books, } \\
\text { library, internet, darkroom } \\
\text { facilities }\end{array}$ \\
\hline \multicolumn{4}{|c|}{ Other curriculum areas/activities that could be integrated \& developed in this ESD study } \\
\hline Economics & & $\begin{array}{l}\text { Economic study of airport, } \\
\text { subdivisions, roading, } \\
\text { parks }\end{array}$ & KCDC, property developers \\
\hline \multicolumn{4}{|l|}{$\begin{array}{l}\text { Health and } \\
\text { Physical Education }\end{array}$} \\
\hline Drama & & $\begin{array}{l}\text { Productions highlighting } \\
\text { issues }\end{array}$ & $\begin{array}{l}\text { Sir John Trimmer, Coasters } \\
\text { Society, Kapiti Players, Dance } \\
\text { Schools }\end{array}$ \\
\hline ICT & & Databases, spreadsheets & ICT teachers \\
\hline $\begin{array}{l}\text { e-Waste \& } \\
\text { recycling }\end{array}$ & & $\begin{array}{l}\text { Attendance at national } \\
\text { e-Day as volunteers }\end{array}$ & $\begin{array}{l}<\text { www.canz.org.nz }> \\
<\text { www.eday.org.nz }>\end{array}$ \\
\hline Recycling waste & & $\begin{array}{l}\text { Composting and worm } \\
\text { farms }\end{array}$ & KCDC Green Gardener service \\
\hline Politics & & $\begin{array}{l}\text { Studying impact of } \\
\text { democratic processes }\end{array}$ & Local MPs and councillors \\
\hline
\end{tabular}

Figure 1 Curriculum Outline "Making a Difference in the Raumati Wetlands"
Figure 1 above provides a chart of suggested curriculum areas which would be well-served by a place-based education approach centred on a topic like the Raumati Wetlands.

\section{Conclusion}

The Ministry of Education rightly says that effective environmental education will occur when students' learning needs are considered and when the issues chosen for study are meaningful and relevant to them. It says students who participate in communities have a strong sense of belonging, with a confidence to participate and contribute within new contexts of learning (2007, p. 13). Children are naturally curious, bringing enquiring minds to learning. They have fresh innovative approaches to problems and a yearning to be free of the classroom. Students learn well in real world settings of "educational biodiversity" and they welcome the opportunity to make a positive impact while they participate in their community and have their voices heard (Bolstad, 2005).

It makes developmental sense to progress from near to far - to use the schoolyard, the neighbourhood, and the adjacent marshlands as a context for learning from kindergarten to sixth grade. It's the Russian doll of curriculum development. (Sobel, 2004, p. 20)

Sobel goes on to advise that schools uncover and cultivate the unique genius of the local environment and community via the school curriculum. A local example is Queen Charlotte College in Picton, where students "own" a mussel line and monitor its growth while trialling products like ropes and growing surfaces for the mussel industry. These students were the first to detect the Didemnum Vexillum (sea squirt) threat to the mussel and salmon farms in Queen Charlotte Sound. Their contribution was real and pertinent and demonstrates the potential value to students, schools, community and industry provided by place-based education. They can take these skills developed at local level and transfer them to their wider world as they proceed to tertiary study and the work environment, while still keeping one eye on the local environment they identify with.

Bolstad (2005) sees these as the sorts of new ideas that need to be embraced if education for sustainable development is to flourish successfully in our schools. Eco-justice needs to be part of school culture, principles and practice while it undertakes a new role as facilitator for the whole community to learn together. She cites New Zealand and 
international research as showing a whole-school commitment is fundamental for schools becoming "place-conscious" or "sustainable" schools (p. 230). Sobel (2004) agrees that by adapting curriculum to local conditions, a different and unique learning evolves. By becoming players in a community ecosystem, teachers and students improve the health of the environment and help fulfil community aspirations.

This would be a wonderful outcome for place-based education centred at the Wharemauku wetlands of Raumati South. The Raumati South Residents' Group has organized other plantings, resulting in stands of cabbage trees now framing the entrance to the swamp, against a background of flaxes, so the scene is set and the groundwork is being done for promoting place-based education in local schools and beyond.

You don't learn about ecology so you can help protect nature in the future. You learn so you can make a difference here and now. (Sobel, 2004, p. 12)

\section{Notes}

1 Western Link road is proposed from Raumati South to Waikanae, to reduce local traffic volume on State Highway 1. Construction at the northern end begins in 2008, while the southern end is not expected before 2115 .

2 NIMBY is the acronym for "not in my back yard".

3 The late Rod Donald was co-leader of the NZ Green Party at the time.

4 LEANZ was the original acronym coined in 1995 for Linking Education and Antarctic Research in New Zealand.

\section{References}

Askew, R. (2007, May 28). Otaki's sand dune saviours. Kapiti Observer, p. 11.

Berry, T. (1999). Foreword in E. O'Sullivan. Transformative learning Educational vision for the 21st century. London: Zed Books.

Blundell, K. (2007, October 17). Battle for wetlands goes on. Dominion Post, p. A16.

Bodnar, M. (1999, December). Community project right up Di's street. Elements, 1, 6. (Greater Wellington Regional Council).

Bolstad, R. (2005). Environmental education: A place in the curriculum? New Zealand Annual Review of Education, 14, 215-235.

Bowers, C. A. (2001). Educating for eco-justice and community. Athens \& London: University of Georgia Press,
Brown, C., \& Dannenmann, K. (2002, Fall). A pedagogy of the land: Dreams of respectful relations. McGill Journal of Education, 37(3), 451-468.

Buchanan, I. (2007). Be the difference programme. Wellington: Greater Wellington Regional Council. <www.bethedifference.gw.govt.nz>.

Cameron, J. I. (2004). Some implications of Malpas' place and experience for place ethics and education. Environmental $\mathcal{E}$ Architectural Phenomenology Newsletter. Retrieved on October 16, 2006, from $<$ www.arch.ksu.edu/seamon/Cameron_malpas.htm $>$.

Carkeek, W. W. (1967). The Kapiti Coast: Maori history and place names of the Paekakariki-Otaki district. Auckland: Reed Publishing (NZ) Ltd.

Carter, L. (2005). Naming to own: Place names as indicators of human interaction with the environment. Alternative - An International Journal of Indigenous Scholarship, 1(1), 6-25.

"Common" butterflies fighting for survival. (2007, March 5). Dominion Post.

Cooper, G. (1996). Alda Leopold and the values of the native. In W. Vitek \& W. Jackson (Eds.), Rooted in the land: Essays on community and place (pp. 150-160). New Haven and London, Yale University Press.

Fox, M. (2008, May 12). Whareroa grateful for grant. Kapiti Observer, p. 8.

Fox, N., \& Wynn, C. (2007, December 13). Falcons return to Wairau Plain. Press release. <www.falconsforgrapes.org $>$.

Gawith, G. (2007). 2007 - The year of the pedagogue. Good Teacher Magazine (Term One), 7-10.

Gilbert, J., Hipkins, R., \& Cooper, G. (2005, May/June). Fact or fiction: Using narrative pedagogy in school science education. Paper presented at the Redesigning Pedagogy: Research Policy and Practice conference, Nanyang University Institute of Education, Singapore.

Gregory, A. (2007, March 29) Godwits' endurance breaks flight record. New Zealand Herald, p. A2.

Gruenwald, D. A. (2003). The best of both worlds: A critical pedagogy of place. Educational Researcher, 32(4), 3-12.

Gurunathan, K. (2007, February 15). Field course thrills migrating bird followers. Kapiti Observer, p. 4.

Gurunathan, K. (2007, April 30). Rubbish-free harvest fair. Kapiti Observer, p. 9. 
Gurunathan, K. (2007, May 3). Book explains journey to creating a special place. Kapiti Observer, p. 35.

Gurunathan (2007, May 31). Fears rare orchid lost at airport. Kapiti Observer, p. 14.

Hawthorne, L. (n.d.). Environmental education primary unit: Streams and waterways: Strife in Streamsville. Wellington: Ministry of Education. Retrieved on Jun 12, 2007, from <www.tki.org.nz/r/environ_ed/ primary_units/streams_water_e.php $>$.

Haxton, D. (2007, March 14). Marvellous marine workers clear beach. Kapiti News, p. 1.

Hutchinson, D. (2004). The meaning of place in education. Chapter 1 in A natural history of place in education (pp. 9-25). New York and London: Teachers College, Columbia University.

Infoxchange Australia. (2007). Reflections project. Melbourne: Infoxchange Australia; Technology for Social Justice. Retrieved on June 12, 2007, from < www.infoxchange.net.au>.

Irvine, M. (2007, April 19). Butterfly taggers keep tabs on monarchs. Kapiti Observer, p. 16.

Jones, J. (2008, January 10). Work stops for falcon family. Gisborne Herald, p. 2.

Kapiti Coast District Council. (1999). A guide to growing native plants in Kapiti. Wellington: Natural Textures Landscape Ecology Information Graphics Ltd.

Karori Sanctuary. (2008). Education programme. Retrieved on January 16, 2008, from <www.sanctuary.org.nz/education/index.html>.

Kawagley, A. O. (2000). Remembering place. In Roger Neil (Ed.), Voice of the drum: Indigenous education and culture (pp. 101-120). Brandon, Manitoba, Canada: Kingfisher Publications.

Kerehi, Jason. (2005, June). Nga wahi tapu o Ngati Hamua: Sacred sites of Ngati Hamua - Paramount hapu of Rangitane o Wairarapa. Paper presented at The Indigenous Knowledges Conference, Victoria University of Wellington.

Light, L. (2007, Winter). Madame butterfly. AA Directions, 21.

Linking Education and Antarctic Research in New Zealand. (2008). Virtual fieldtrips for New Zealand schools. Retrieved on January 16, 2008, from <www.learnz.org.nz/index.php >.
McLean, G. (2006). How to do local history. Dunedin: Otago University Press.

Macmorran, B. (1977). In view of Kapiti. Palmerston North: Dunmore Press.

Marsden, Maori. (2003). Kaitiakitanga: A definitive introduction to the holistic world view of the Maori. In Te Ahukaramu Charles Royal. (Ed.), The woven universe - Selected writings of Rev Maori Marsden (pp. 54-72). The estate of Rev. Maori Marsden.

Ministry of Education. (1999). Planning environmental education programmes within the New Zealand curriculum framework. In Guidelines for environmental education in New Zealand schools. Wellington: Ministry of Education. Retrieved on June 12, 2007, from $<$ www.tki.org.nz/r/environ_ed/guidelines/plan_enviro_e.php $>$

Ministry of Education. (2007). The New Zealand Curriculum: For Englishmedium teaching and learning in years 1-13. Wellington: Learning Media Limited.

Muller, C. (2002). Revegetation plan Raumatiwetlands. Wellington: Greater Wellington Regional Council.

New Zealand Association for Environmental Education Inc. (2007). Draft curriculum update. Wellington: NZAEE. Retrieved on June 12, 2007, from < www.nzaee.org.nz/events_news.htm >.

Park, G. (1996). Nga ururoa - The groves of life: Ecology and history in a New Zealand landscape. Wellington: Victoria University Press.

Price, V. (2007, February 8). Frog finding: University hunting gardens. Kapiti Observer, p. 27.

Rangitane o Wairarapa \& Greater Wellington Regional Council. (2005). Ngati Hamua environmental education sheets. Masterton: Lamb-Peters Print.

Raumati South Residents' Group. (2007, May). Raumati South Residents' Group Newsletter, Four.

Rogers, L. (2007). There is a little town by the sea somewhere. Good Teacher Magazine (Term Two), 14-16.

Smith, G. A. (2002). Place-based education - Learning to be where we are. Phi Delta Kappan 83(8), 584-96. Retrieved on December 21, 2005, from $<$ http://helicon.vuw.ac.nz>. 
Smith, G. A. \& Williams, D. R. (Eds.). (1999). Introduction. In Ecological education in action - On weaving education, culture, and the environment (pp. 1-18). Albany, NY: State University of New York Press.

Sobel, D. (2004). Place-based education - connecting classrooms and communities. Great Barrington, MA: Orion Society.

Starting a community project. (1999, October 30). Kapiti Observer, p. 2.

Sturgess, A. (2007). A question often asked: Where have the values gone? Good Teacher Magazine. (Term One), 16-18.

Te Kete Ipuranga. (2003). Living heritage; tikanga tuku iho: Students capturing tomorrow's history today. Wellington: Ministry of Education $<$ www.livingheritage.org.nz>

Walker, R. (2007, A pril 16). Hospital land for subdivision. Kapiti Observer, p. 1.

Woodhouse, J L., \& Knapp, C. E. (2000). Place-based curriculum and instruction: Outdoor and environmental education approaches. ERIC Digest. Retrieved on May 21, 2008, from

$<$ www.ericdigests.org/2001-3/place.htm $>$.

\section{The author}

Di Das is a MEd graduate in Maori and Pacific Nations Education from Victoria University of Wellington. Her interest lies in empowerment education for underserved communities, and she is the National Coordinator for the Computers in Homes programme. She has presented at Global Knowledge Partnership, Connecting Communities and Third Sector Research Conferences in Malaysia, NZ and India.

She originally had a science and primary teaching background and is passionate about the environment. She is a member of the New Zealand Raptor Association, assisting with field research. She taught Te Tiriti O Waitangi and Anti-racism Education for numerous tertiary institutions for fifteen years and remains committed to promoting equitable educational outcomes for all. 